\title{
Feeding and egg production of Oithona similis in the North Atlantic
}

\author{
Claudia Castellani ${ }^{1,3,4, *}$, Xabier Irigoien ${ }^{2}$, Roger P. Harris ${ }^{3}$, Richard S. Lampitt ${ }^{1}$ \\ ${ }^{1}$ Southampton Oceanography Centre Waterfront Campus, European Way, Southampton SO14 3ZH, UK \\ ${ }^{2}$ AZTI (Fisheries and Food Technological Institute), Herrera Kaia Portualdea, 20110 Pasaia, Spain \\ ${ }^{3}$ Plymouth Marine Laboratory, Prospect Place, Plymouth PL1 3DH, UK \\ ${ }^{4}$ Present address: BODC (British Oceanographic Data Centre), Proudman Oceanographic Laboratory, 6 Brownlow Street, \\ Liverpool L3 5DA, UK
}

\begin{abstract}
Although cyclopoids of the genus Oithona are considered the most abundant copepods in the marine environment, there is still very little information about what sustains their population and almost constant reproduction rate throughout the year. Feeding and egg production rate (EPR) of $O$. similis were measured at coastal and oceanic stations during 3 cruises in the North Atlantic between April and November 2002. O. similis ingested ciliates preferentially to other components of the nano- and microplankton (herein nano-microplankton), which only became a more important component of the copepod diet when the abundance of the former decreased to low concentrations. EPR did not show significant seasonal differences, with $2.13 \pm 0.67$ eggs female ${ }^{-1} \mathrm{~d}^{-1}$ in spring, $1.61 \pm 0.32$ eggs female $\mathrm{e}^{-1} \mathrm{~d}^{-1}$ in summer and $1.60 \pm 0.15$ eggs female $\mathrm{e}^{-1} \mathrm{~d}^{-1}$ in winter. The ingestion rates measured at many oceanic stations and in winter were often too low to sustain EPR. Egg production efficiency (GGE) $>100 \%$ indicated that sustained EPR might have relied, particularly in winter, on alternative food sources such as a more carnivorous diet and/or on the faecal pellets of euphausids.
\end{abstract}

KEY WORDS: Oithona similis · Cyclopoids · Feeding rate · Egg production rate - Microzooplankton · Gross growth efficiency

\section{INTRODUCTION}

Oithona spp. is probably the most abundant and cosmopolitan copepod group throughout coastal and oceanic regions of tropical, temperate and polar waters (Paffenhöfer 1993, Nielsen \& Sabatini 1996, Atkinson 1998, McKinnon \& Klumpp 1998). These cyclopoids usually constitute a significant fraction of the total copepod numbers, and thus their grazing may be equivalent to that of calanoid copepods (Atkinson 1996). However, unlike free-spawning calanoids which show very strong seasonal signals in both population abundance and reproduction rate, Oithona spp. has been reported to maintain almost constant weight-specific egg production (SEPR) year-round (Sabatini \& Kiørboe 1994), and relatively high population abundance in winter when other copepod groups decline
(Nielsen \& Sabatini 1996). It has been argued that such differences in seasonality may be related to differences in the functional relationship between fecundity and food availability rather then differences in reproductive strategies between calanoid and cyclopoids (Kiørboe \& Sabatini 1994, Sabatini \& Kiørboe 1994). Oithona spp. has been reported to prefer motile to non-motile prey (Uchima \& Hirano 1986, Turner \& Graneli 1992), selecting ciliates preferentially to diatoms of similar shape and size (Atkinson 1996), and to be able to feed carnivorously (Lampitt 1978, Nakamura \& Turner 1997) and coprophagously (Gonzalez \& Smetacek 1994). Nevertheless, phytoplankton, particularly diatoms, can also make up a large fraction of the diet of Oithona spp. (Hopkins et al. 1993, Atkinson 1996).

The relative importance of different food items within the natural diet of Oithona spp. and their direct 
contribution to egg production still remains uncertain (Paffenhöfer 1993, Atkinson 1998). One reason for such a shortcoming is that there has been no single comprehensive study considering the feeding and reproductive ecology of Oithona spp. at different times of the year in contrasting situations of relatively food-rich shelf areas and relatively food-poor open ocean waters. Although protozoans can be the most important food source of Oithona spp. in spring in coastal areas, their dietary contribution to reproduction is unknown. In addition, it is also unclear whether the relatively high reproductive activity in winter and in the open ocean can be fuelled by a diet of small flagellates $<<5$ to $10 \mu \mathrm{m})$, which may represent the most abundant food source in many temperate areas (Sabatini \& Kiørboe 1994), or by a more carnivorous diet (Atkinson \& Shreeve 1995).

The present study investigates the relationship between feeding and fecundity of Oithona similis during 3 cruises in the North Atlantic at coastal and oceanic stations. In particular we asked the following questions: (1) Which food source is likely to sustain $O$. similis egg production at different times of the year? (2) Can a diet of flagellates alone sustain $O$. similis reproduction in winter and in open waters?

\section{MATERIALS AND METHODS}

Feeding experiments. The feeding rates of Oithona similis were measured during shipboard experiments carried out during RRS 'Discovery' cruises D262, D264 and D267 in the Irminger Basin in spring, summer and autumn-winter 2002 respectively. Experimental stations are presented in Fig. 1.

The Oithona similis for the feeding experiments were picked from $63 \mu \mathrm{m}$ net samples vertically collected from $120 \mathrm{~m}$ depth at each experimental station. Feeding rates on the different nano- and microplanktonic groups were estimated by incubating 15 to 25 adult female $O$. similis in $200 \mathrm{ml}$ bottles filled with water from the chlorophyll a ( $\mathrm{chl}$ a) maximum. We incubated 3 replicates and 3 control bottles on a plankton wheel $(1 \mathrm{rpm})$ for $24 \mathrm{~h}$ in the dark at the mixedlayer temperature. An additional bottle was filled and immediately fixed to estimate the abundance at the start of the experiment. At the end of the experiment Lugol's iodine was added to the bottles to a final concentration of $2 \%$ (Nielsen \& Kiørboe 1994). Half of the bottle volume was settled (Utermöhl 1958) and counted with an inverted microscope (following Båmstedt et al 2002). Heterotrophic dinoflagellates were separated from autotrophic forms according to taxonomical criteria (Lessard \& Swift 1986, Burkill et al 1993). Cell volume was converted to carbon according to Strathmann (1967) for phytoplankton and using a

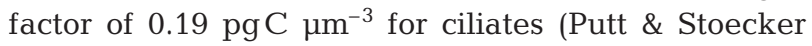
1989). Filtration and ingestion rates in the incubations were calculated according to the equation of Frost (1972) for the taxa where there was a significant difference in abundance between controls and incubation bottles. Food selection on specific phytoplankton groups/species was quantified using the selectivity index proposed by Manly (1974) for variable prey populations.

Egg production rates. The egg production rates (EPR) of the Oithona similis population were calculated at each station using the female-to-egg ratio method (Edmondson 1971), by counting the eggs per sac and the number of females extracted from the preserved $63 \mu \mathrm{m}$ net samples vertically collected from $120 \mathrm{~m}$ depth at each experimental station. The egg hatching rate at the temperature measured at each station was calculated using the equation of Nielsen et al (2002). We dissected 30 egg sacs, and sized and counted the eggs under an inverted microscope. Egg carbon content was estimated from egg volume assum-

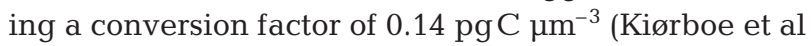
1985, Huntley \& Lopez 1992). The prosome length of 30 females was measured in the same way as for the eggs, and the length was converted to carbon by means of the length-weight regression of Sabatini \& Kiørboe (1994).

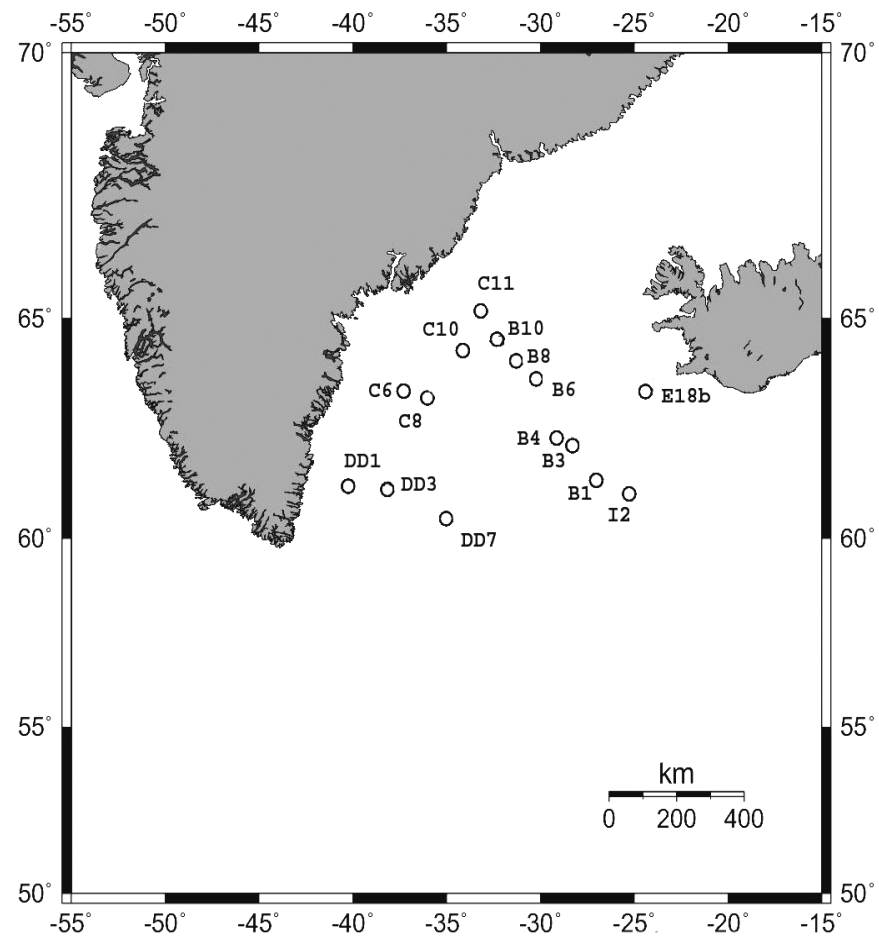

Fig. 1. Map of study area in the Irminger Basin showing station positions 


\section{RESULTS}

\section{Feeding environment}

The composition and biomass of the nano-microplankton differed substantially both during the 3 cruises and across stations (Fig. 2, Table 1). In spring the nano-microplankton in the Irminger Basin (10 to $169 \mathrm{mg} \mathrm{C} \mathrm{m}^{-3}$ ) was dominated by ciliates (Strombidium spp. 20 to $30 \mu \mathrm{m}$, and Myrionecta spp. $>30 \mu \mathrm{m}$ ) and nanoflagellates $(5 \mu \mathrm{m})$. On the Greenland shelf, Phaeo-
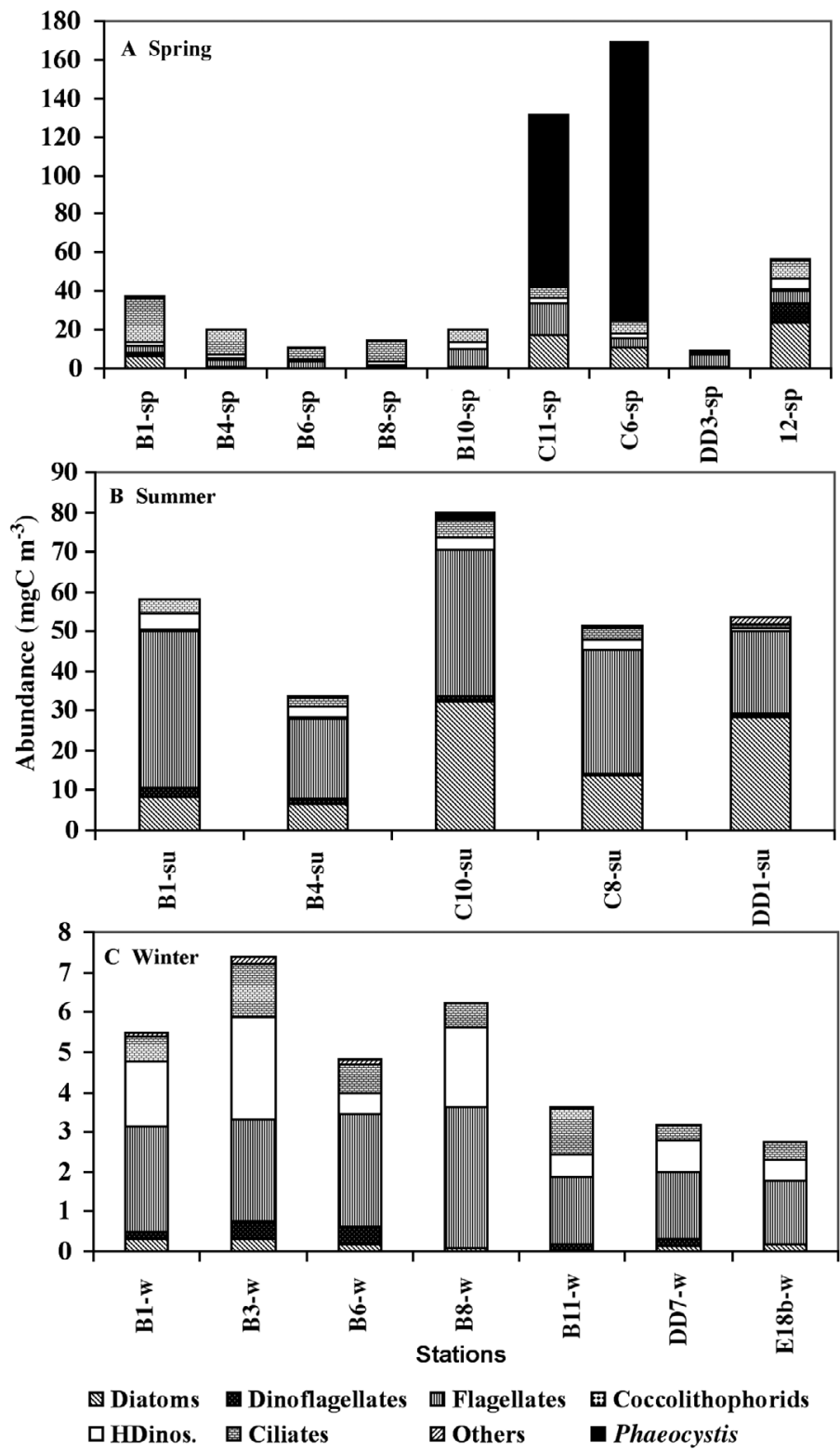

Fig. 2. Initial composition and concentration of different nanoand microplankton groups at different stations in spring, summer and winter. Stations numbered as in Fig. 1 (sp: spring; su: summer; w: winter). HDinos.: heterotrophic dinoflagellates cystis sp. and diatoms made up most of the biomass (i.e. $>80 \%$ ). In the Iceland Basin, the nano-microplankton community was dominated mostly by diatoms (Chaetoceros pelagicus) whereas the contribution of dinoflagellates (Dinophysis acuminata, Gyrodinium britannicum), Strombidium spp. and small flagellates (2 to $5 \mu \mathrm{m}$ ) was less important than at the other stations.

In summer, the total nano-microplankton biomass on the Greenland Shelf, ranging from 51.6 to $79.6 \mathrm{mgC}$ $\mathrm{m}^{-3}$, was lower than in spring. At this time the nanomicroplankton was often dominated by small flagellates $(2$ to $5 \mu \mathrm{m})$ throughout all stations, whereas diatoms, particularly the genus Tropidoneis spp., were the second most important group.

In the autumn and winter, sampling was conducted in the Irminger Basin and off the coast of Iceland but not on the Greenland Shelf due to bad weather conditions. At this time, the nano-microplankton biomass was much lower than on the previous 2 cruises, ranging between 3.3 and $\sim 8 \mathrm{mg} \mathrm{C} \mathrm{m}^{-3}$. Again flagellates dominated the biomass at most stations, whereas dinoflagellates and ciliates alternated in order of importance.

\section{Feeding}

Oithona similis ingestion rates ranged from 8.4 to $113.1 \mathrm{ngC}$ female $\mathrm{e}^{-1} \mathrm{~d}^{-1}$ in spring, 22.5 to $96.3 \mathrm{ngC}$ female ${ }^{-1} \mathrm{~d}^{-1}$ in summer, and 1.2 to $8.6 \mathrm{ngC} \mathrm{female}^{-1} \mathrm{~d}^{-1}$ in winter (Fig. 3). Ingestion rates were correlated with the total initial carbon concentration during spring except for those stations where Phaeocystis spp. dominated the microplankton. In summer and winter, ingestion rates were not correlated with carbon concentration and were overall lower than in spring. Feeding

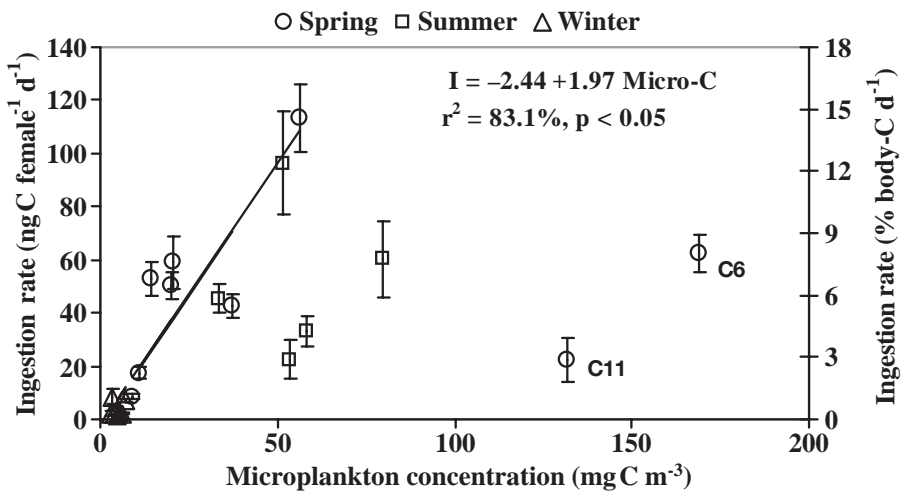

Fig. 3. Oithona similis. Mean $( \pm \mathrm{SD})$ ingestion rates (I) as a function of initial total carbon concentration. Regression line fitted to spring data excludes Stns C6-sp and C11-sp, which were dominated by Phaeocystis spp. colonies and the winter and summer stations 


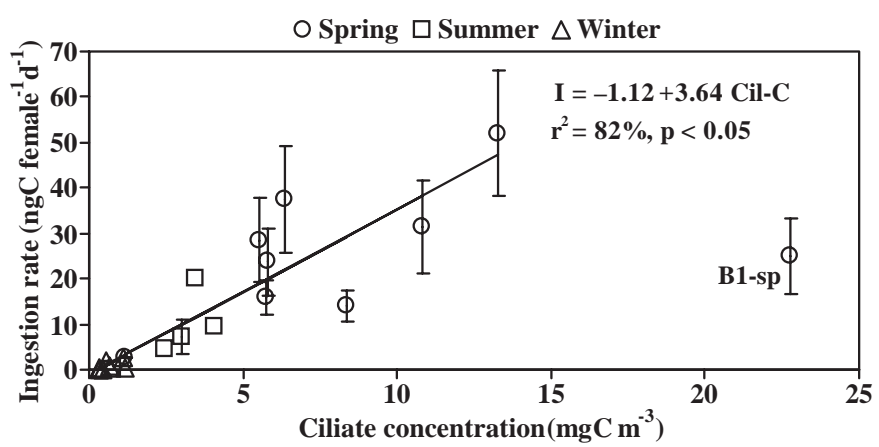

Fig. 4. Oithona similis. Mean $( \pm \mathrm{SD})$ ingestion rates (I) as a function of total initial ciliate carbon (Cil-C) concentration. Regression line fitted to whole data set excluding Stn B1-sp, which was dominated by Myrionecta spp.

rates on ciliates in different seasons were overall positively correlated with ciliate abundance (Fig. 4).

\section{Clearance rates and prey selection}

During spring, Oithona similis females ingested ciliates (Strombidium spp. and Myrionecta spp.) and flagellates preferentially to other nano-microplankton. Phaeocystis spp. were never ingested even when they made up the largest proportion of the nano-microplankton carbon (Table 1, Stns C6-sp and C11-sp). In the Iceland Basin in spring at Stn I2-sp, where the largest proportion of the nano-microplankton was represented by diatoms Chaetoceros pelagicus, $O$. similis ingested dinoflagellates Dinophysis acuminata, flagellates $(2 \mu \mathrm{m})$ and ciliates, which were less abundant than diatoms.

In summer and winter, whenever the proportion of ciliates in the nano-microplankton decreased to very low abundances, the flagellate and the pennate diatoms Tropidoneis spp. made up the largest part of the Oithona similis diet. Overall, the highest clearance rates were generally measured for ciliates, particularly Strombidium spp. and Myrionecta spp. However, other less-abundant prey such as coccolithophorids and dinoflagellates could also be filtered at high rates, particularly when ciliates were scarce (Table 1).

\section{EPR and GGE}

The Oithona similis EPR was very variable, both temporally and spatially. As a result, although mean $( \pm \mathrm{SD})$ EPR was on average higher in spring $(2.1 \pm 0.7$ eggs female $\left.^{-1} \mathrm{~d}^{-1}\right)$ than in summer $\left(1.6 \pm 0.3\right.$ eggs female $\left.{ }^{-1} \mathrm{~d}^{-1}\right)$ and winter $\left(1.6 \pm 0.2\right.$ eggs female $\left.{ }^{-1} \mathrm{~d}^{-1}\right)$, the difference in fecundity between seasons was on average not significant (ANOVA, $\mathrm{df}=19, F=2.99, \mathrm{p}=0.77$ ). The mean

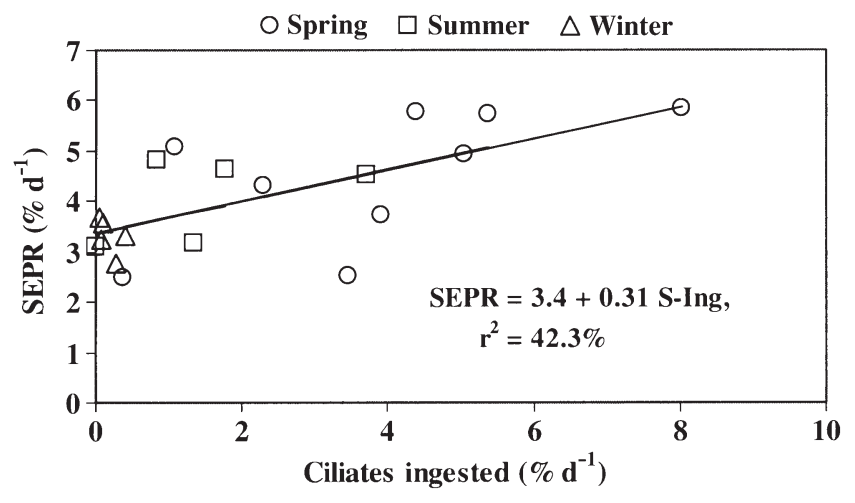

Fig. 5. Oithona similis. Relationship between weight-specific egg production rate (SEPR) and weight-specific ingestion (S-Ing) rates of total ciliates

prosome length $( \pm \mathrm{SD})$ of the $O$. similis females at the experimental stations ranged from $505 \pm 11 \mu \mathrm{m}$ (or $650 \pm 3 \mathrm{ng} \mathrm{C}$ ) in winter, $510 \pm 25 \mu \mathrm{m}$ (or $680 \pm 8 \mathrm{ng} \mathrm{C}$ ) in spring, and $498 \mu \mathrm{m} \pm 24$ (or $540 \pm 3 \mathrm{ng} \mathrm{C}$ ) in summer. On the other hand, egg size did not vary with season averaging $( \pm \mathrm{SD}) 60 \pm 8 \mu \mathrm{m}$ in diameter.

The relationship between EPR and nano-microplankton ingested mirrored the pattern found between ingestion and food concentration. Overall, there was no correlation between EPR and total nano-microplankton carbon ingested whereas there was a significant relationship between SEPR and total ciliates ingested at all stations (Fig. 5). Comparison between ingestion rate and EPR showed that copepods reproduced at very low or no ingestion, suggesting that feeding might have been underestimated at some of the stations. This observation was confirmed by the generally high (i.e. $>100 \%$ ) estimates of egg production efficiencies (i.e. GGE $=$ EPR/ ingestion rate $\times 100$ ) that were obtained at several stations. Comparison between the ingestion rates calculated from EPR (i.e. assuming GGE of $30 \%$, Ikeda \& Motoda 1978) with the ingestion rates measured from feeding experiments at each station suggests that the underestimation of ingestion rates was probably most severe during winter (Fig. 6). Excluding the stations at which GGE was $>100 \%$, we estimated a mean GGE of $47 \pm 16 \%$. Fig. 7 also shows that there was a positive relationship between GGE $<100 \%$ and the percentage of ciliates in the diet, indicating that microzooplankton had higher nutritional quality for Oithona similis than other components of the nano-microplankton.

\section{DISCUSSION}

\section{Ingestion rates and food selection}

The wide variety of nano-microplankton composition and abundance encountered at the North Atlantic 


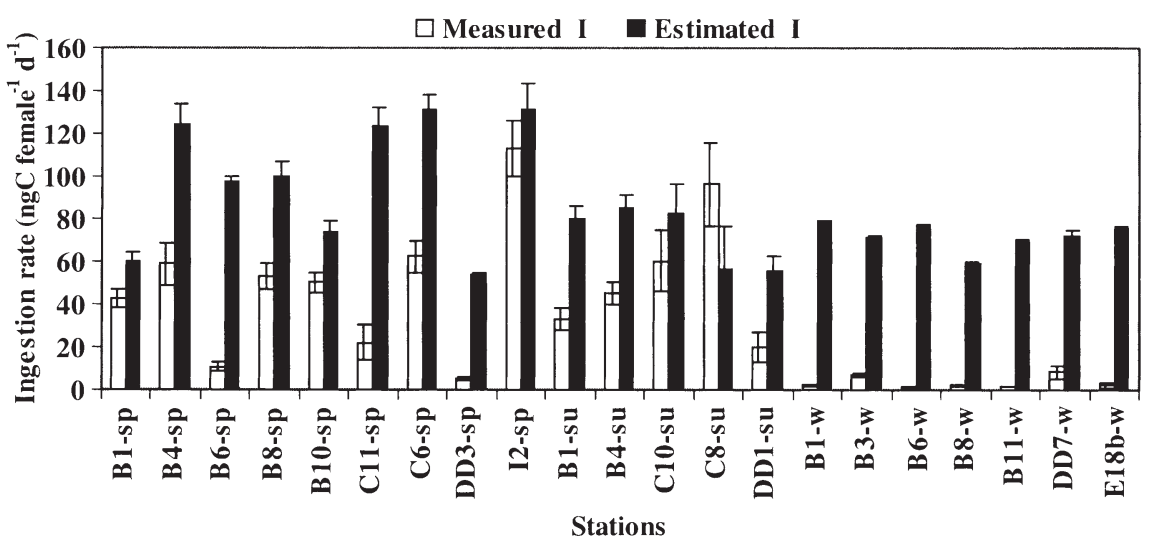

Fig. 6. Oithona similis. Comparison between ingestion rates $(\mathrm{I}, \pm \mathrm{SD})$ measured in feeding experiments and those estimated from EPR assuming an egg production efficiency (GGE) of $30 \%$

stations during the year, in the present study, enabled the feeding ecology of Oithona similis to be investigated in some detail. The spatial and seasonal variation in the ingestion rates of adult females was related to both the abundance and the composition of the nano-microplankton. The highest ingestion rates were measured in spring and summer when nano-microplankton abundance was high, and the lowest in winter when abundance declined. The significance in the relationship between ingestion and nano-microplankton standing stock in spring, however, appeared to be related to the higher ciliate abundance found at this time of the year compared to summer and winter (Fig. 3). This observation is clearly supported by the significant relationship found between ingestion rates and abundance for the whole data set when total ciliates alone were considered (Fig. 4).

Oithona similis did, in fact, clear ciliates at a higher rate than the other more abundant nano-microplankton

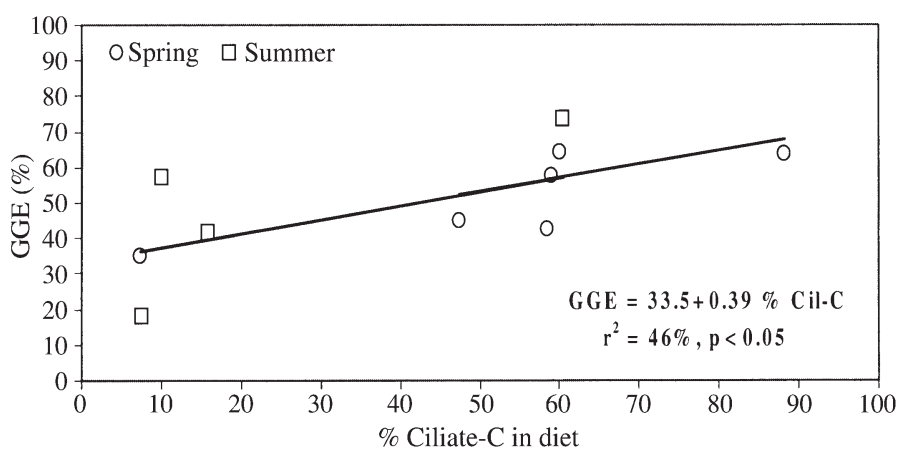

Fig. 7. Oithona similis. Relationship between egg production efficiency (GGE) and percentage carbon in diet of females at different stations. Regression line fitted to data excluding GGE $>75 \%$ organisms, indicating that it was feeding selectively on this group (Table 1). Similarly, Atkinson (1996) found that $O$. similis cleared ciliates faster than phytoplankton (i.e. centric diatoms) of similar size. The highest clearance rates were measured for $O$. similis feeding on Strombidium spp. 20 to $30 \mu \mathrm{m}\left(23 \mathrm{ml}_{\text {female }}^{-1} \mathrm{~d}^{-1}\right)$, which often also comprised the largest proportion of the diet of these copepods. The maximum clearance rates measured here on ciliates are within the reported range for $O$. similis: from $\sim 7 \mathrm{ml}$ female ${ }^{-1} \mathrm{~d}^{-1}$ (Atkinson \& Shreeve 1995) to $\sim 75 \mathrm{ml}$ female ${ }^{-1} \mathrm{~d}^{-1}$ (Lonsdale et al. 2000). High clearance rates in this study were also measured on Myrionecta spp. (Table 1). Although the importance of microzooplankton and ciliates in the diet of Oithona spp. has been recognised by other studies for other environments (Atkinson 1996, Nielsen \& Sabatini 1996, Nakamura \& Turner 1997, Lonsdale et al. 2000), none of the previous investigations have reported predation of Oithona spp. on Myrionecta spp. Copepod feeding efficiency is related to the different characteristics of their prey, including abundance, shape, size, behaviour and palatability and the predator itself (behaviour, hunger, etc.). The ability of $O$. similis to prey on such fast-swimming ciliates must be attributed to a combination of very high jump speeds and the reduced hydrodynamical disturbance characteristic of the genus Oithona (Svensen \& Kiørboe 2000, Paffenhöfer \& Mazzocchi 2002). Although O. similis preyed on Myrionecta spp., it is likely that its feeding efficiency on this prey might have been lower than that on other ciliates. The low ingestion rates measured in spring at Stn B1-sp (Fig. 4), where the highest biomass of ciliates was found, may probably be attributable to the low capture efficiency of $O$. similis feeding on Myrionecta spp., which dominated the ciliate assemblage (i.e. $54 \%$ of total ciliate carbon). It is also interesting that, although the maximum ciliate abundance $\left(24.4 \mathrm{mg} \mathrm{C} \mathrm{m}^{-3}\right)$ measured by Lonsdale et al. (2000) was similar to the maximum $\left(23.5 \mathrm{mg} \mathrm{C} \mathrm{m}^{-3}\right)$ measured in the present study at Stn B1-sp (Fig. 4), the filtration rates reported by Lonsdale et al. (2000) of $\sim 75 \mathrm{ml}$ female ${ }^{-1} \mathrm{~d}^{-1}$ at $0^{\circ} \mathrm{C}$ were $\sim 8$ times higher than the $\sim 9 \mathrm{ml}$ female ${ }^{-1} \mathrm{~d}^{-1}$ measured here at $7^{\circ} \mathrm{C}$. Nakamura \& Turner (1997) found that the clearance rate of $O$. similis increased with increasing prey volume. Since the ciliates in Lonsdale et al.'s (2000) study were on average larger $\left(2.54 \mathrm{ngC} \mathrm{cell}{ }^{-1}\right)$ than those found in the Irminger Basin $\left(1.39 \mathrm{ng} \mathrm{C} \mathrm{cell}^{-1}\right)$, it is possible that the lower filtration rates in the present study were the result both of lower feeding efficiency 


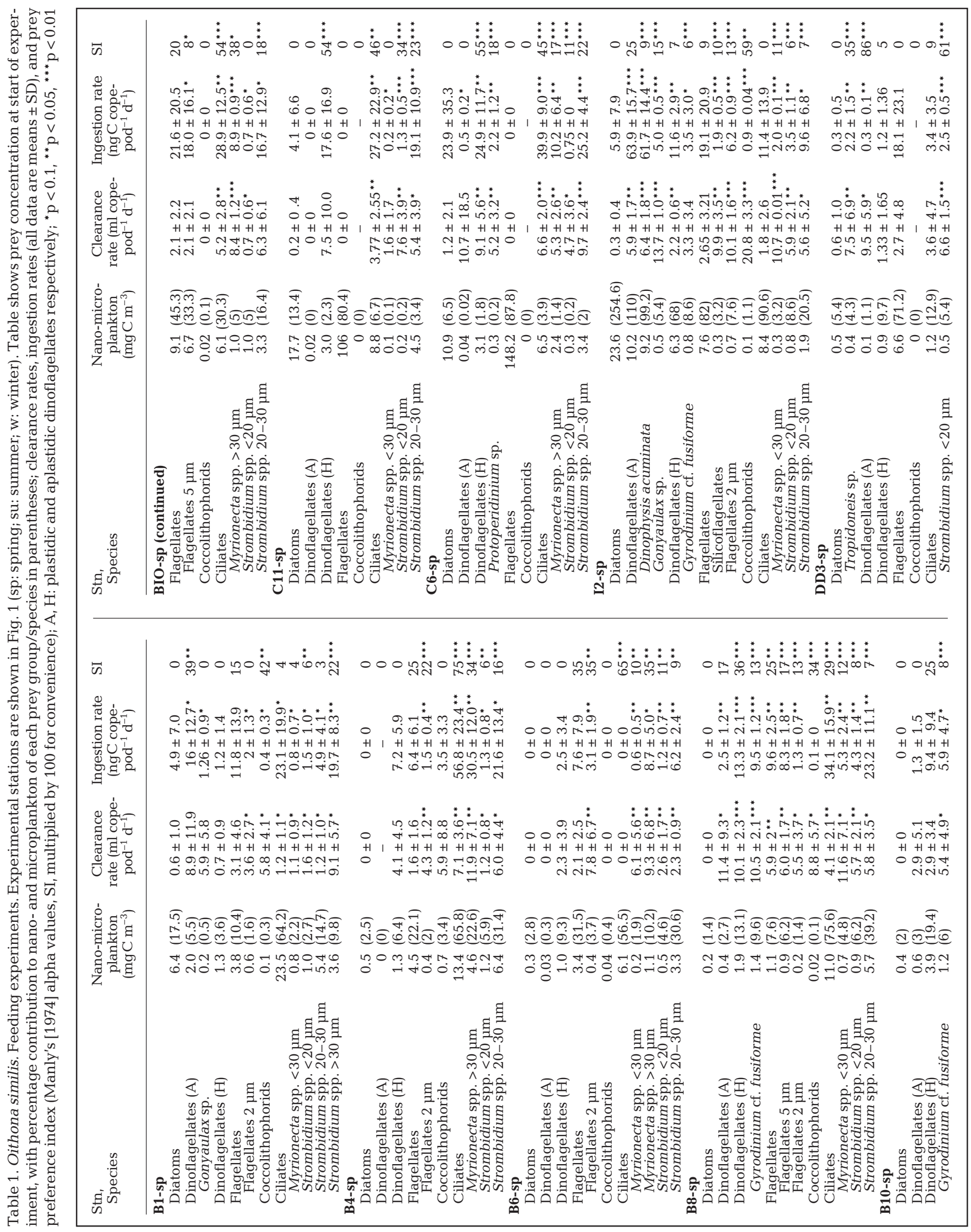




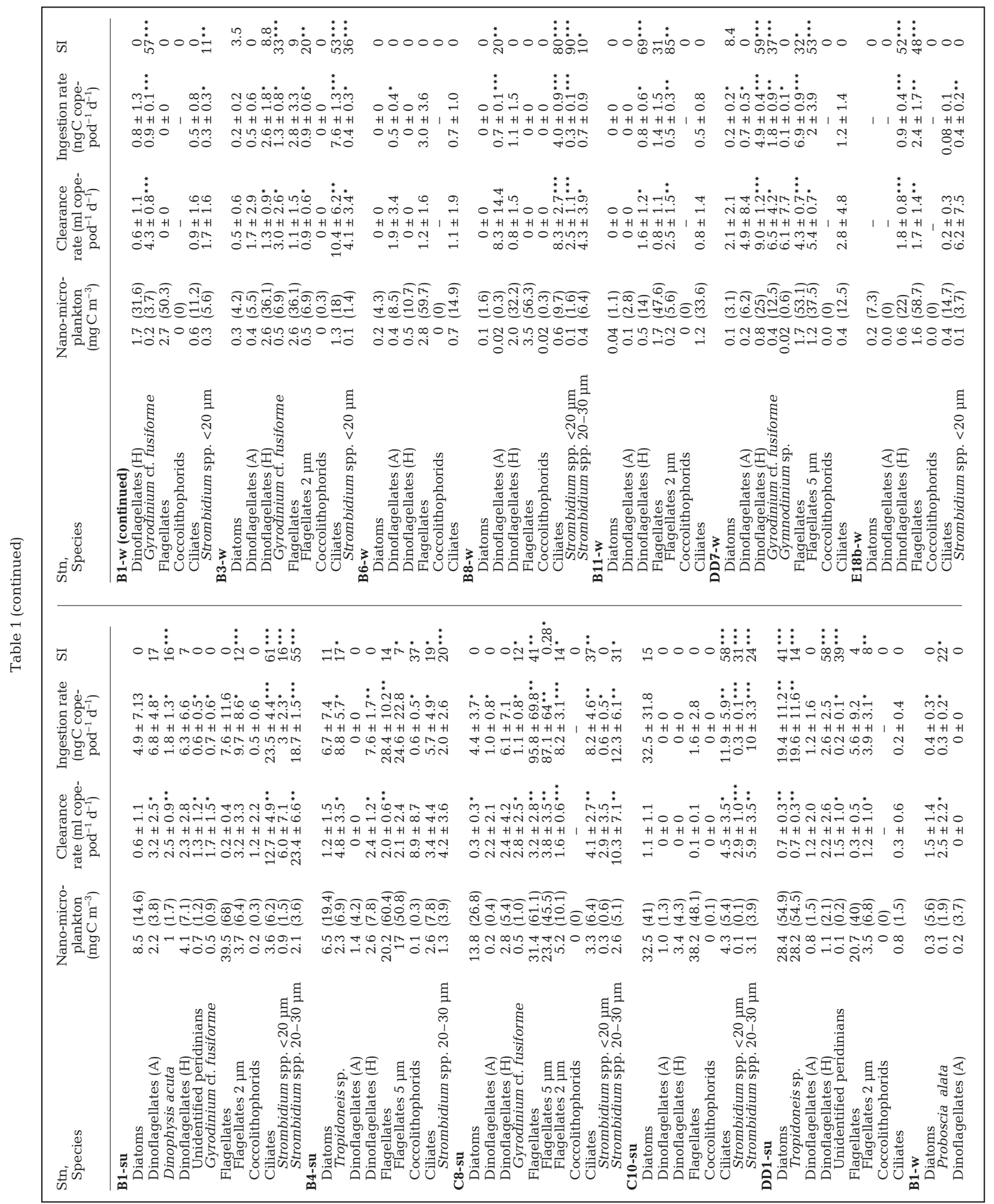


on Myrionecta spp. and lower predation rates on smaller ciliates. However, the linear response of the feeding rates suggests that even in spring, when food sources were highest, ciliate abundance was probably too low to saturate ingestion rates (Fig. 4).

Overall, in the present study Oithona similis appeared to ingest motile prey, particularly ciliates, preferentially to other prey, with the latter only becoming important when the abundance of the former decreased to very low abundance (Table 1). Results from previous studies have presented conflicting evidence on the feeding ecology of Oithona spp. Lonsdale et al. (2000) reported that dinoflagellates were not important in the diet of O. similis, and Nakamura \& Turner (1997) measured lower clearance rates on dinoflagellates (3.12 $\mathrm{ml}$ female ${ }^{-1} \mathrm{~d}^{-1}$ ) than on ciliates (6.24 to $9.12 \mathrm{ml}$ female $\mathrm{e}^{-1} \mathrm{~d}^{-1}$ ) of equivalent spherical diameter (i.e. ESD $20 \mu \mathrm{m})$. In contrast, O. similis in subantarctic seas cleared pennate diatoms (ESD $10 \mu \mathrm{m}$ ) and dinoflagellates (EDS $20 \mu \mathrm{m}$ ) at rates 3 and 1.3 times higher than ciliates (EDS $15 \mu \mathrm{m}$ ) respectively (Atkinson 1996). In Atkinson's (1996) study, however, ciliate carbon concentration was $\sim 2$ to 4 times lower than that of the dinoflagellates and diatoms in his own study, and up to 16 times lower than that of ciliates in the study of Nakamura \& Turner (1997) and in the present study. Thus, consistent with the present study, the higher ingestion rates measured by Atkinson (1996) on diatoms and dinoflagellates were probably due to the very low abundance of ciliates in his study area. Nevertheless, ciliates differ in their locomotory behaviour, i.e. different ciliates probably elicit varying responses from $O$. similis and this might have well been another reason for the difference in prey-type selection measured at different stations in the present study and between the present and previous studies.

Although dinoflagellates did not form a large proportion of the microplankton in the present investigation, they appeared to be ingested preferentially to diatoms whenever present (Table 1). For instance, Dinophysis acuminata was the highest component of the Oithona similis diet in the Iceland basin (Table 1, Stn I2-sp), although the diatom Chaetocerous pelagicus dominated the nano-microplankton biomass. In summer, when ciliate abundance declined at all stations, O. similis had higher feeding rates on both the pennate diatom Tropidoneis spp. (Table 1, Stn DD1-su) and on flagellates (Table 1, Stn C8-su) which accounted for up to $80 \%$ of the diet. High filtration rates of Oithona spp. on pennate diatoms $\left(\sim 12\right.$ female $^{-1} \mathrm{~d}^{-1}$, i.e. calculated from weight-specific filtration rates) have also been reported by Atkinson (1996). Findings from the present study, however, contrast with the measurements of Nakamura \& Turner (1997), who found no evidence of ingestion of 6 to $8 \mu \mathrm{m}$ flagellates by $O$. similis. Never- theless, O. similis can feed, grow and reproduce on a unialgal diet of Rhodomonas reticulata ( $6 \mu \mathrm{m}$ length, C. Castellani pers. obs.) and Oithona spp. have been reported to feed on a variety of cultured flagellate species in other studies (Lampitt \& Gamble 1982, Drits \& Semenova 1984, Kiørboe \& Sabatini 1994). Moreover, the fact that flagellates were ingested at higher rates when Strombidium spp. abundance was lowest (e.g. Table 1, Stns B4-su and C8-su) suggests that the copepods were feeding on them. It is interesting, however, that despite preying on flagellates in the present study, $O$. similis did not ingest Phaeocystis spp. colonies. Overall, these observations indicate that although preying selectively on ciliates, $O$. similis will switch to feeding on more abundant nano-microplankton prey when ciliate abundance declines.

It is also noteworthy that, since Oithona similis was the most abundant copepod species found in the study area throughout the year, accounting for between 40 and $80 \%$ of the total copepod community (C. Castellani pers. obs.), the impact of this species on the nanomicroplankton standing stock was probably quite important.

In the present study, the daily carbon ration of Oithona similis from nano- and microplankton represented on average, 9.5 and $8.2 \%$ body- $\mathrm{C} \mathrm{d}^{-1}$ (max. $17 \%$ ) in spring and summer respectively, but only $0.54 \%$ body- $\mathrm{C} \mathrm{d}^{-1}$ (max. $1.3 \%$ ) in winter. Our maximum values are close to the 12 to $27 \%$ body-C d reported by Nakamura \& Turner (1997) and the $13 \%$ body-C d $\mathrm{d}^{-1}$ measured by Lonsdale et al. (2000) for $O$. similis feeding on total nano- microplankton and ciliates respectively, but lower than the $34 \%$ body-C $\mathrm{d}^{-1}$ estimated by Atkinson (1996) for Oithona spp. feeding on phytoplankton.

At the mean temperatures encountered in the Irminger Basin, the cost of respiration for a female Oithona similis will range from $\sim 6 \%$ body $-\mathrm{C} \mathrm{d}^{-1}$ at $7^{\circ} \mathrm{C}$ in spring and winter and $\sim 10 \%$ body- $\mathrm{C} \mathrm{d}^{-1}$ at $11^{\circ} \mathrm{C}$ in summer (Castellani et al. 2005). Thus, whereas the ingestion rates measured at most of the stations in spring and partly in summer exceeded the cost of basic copepod body maintenance, those measured in winter were well below the energy requirements of the copepods.

\section{SEPR and GGE}

Similarly to ingestion rate, SEPR $\left(\% \mathrm{~d}^{-1}\right)$ of Oithona similis was highly correlated with total ciliates ingested, but not with total nano-microplankton carbon, for all stations. This supports the observation of Nielsen \& Sabatini (1996) of a positive correlation in the EPR of $O$. similis in the North Sea with in situ microzooplankton but not with phytoplankton abundance. Nevertheless, 
the high and significant (i.e. different from zero, Fig. 5) intercept of the regression between SEPR and weightspecific ciliate carbon ingested $\left(\% \mathrm{~d}^{-1}\right)$ indicates that ciliates alone could not have supported reproduction.

The lack of agreement (particularly for the winter stations) between ingestion rates measured and those estimated from EPR (i.e. Fig. 6, assuming an egg production efficiency, GGE of $30 \%$ ) indicates that Oithona similis, ingestion was probably underestimated by the bottle-incubation technique. Oithona spp. is able to feed on a very wide variety of food sources which include, beside unicellular microplankton, the nauplii (Lampitt 1978, Nakamura \& Turner 1997) and faecal pellets (Gonzalez \& Smetacek 1994) of other copepods, neither of which can usually be estimated accurately because of the relatively small volume analysed with this method. Alternatively, the 'bottle effect', i.e. incubation of a relatively large number of copepods in a small volume combined with the turbulence generated by the rotation of the plankton wheel, might have increased the encounter rate of jumping $O$. similis with the wall of the bottle, negatively affecting its mechanoreception of the prey. The copepods used in the present experiment originated from the entire upper $120 \mathrm{~m}$ of the water column, whereas the suspensions for the experiments originated from the chlorophyll maximum. Thus, it is also possible that low ingestion rates were caused by the fact that the $O$. similis food optimum was not in the chlorophyll maximum.

Nakamura \& Turner (1997) have shown that, although a large part of the food source of Oithona similis is comprised of ciliates and flagellates, the calculated ingested food could cover metabolic requirements and egg production only when a carnivorous source was considered in the diet. In a laboratory study, Sabatini \& Kiørboe (1994) could not measure any egg production in O. similis at flagellate concentrations of $<20 \mu \mathrm{g} \mathrm{C}^{-1}$ and Lampitt \& Gamble (1982) measured food-saturating conditions for $O$. nana only at flagellate concentrations $>100 \mu \mathrm{gC}^{-1}$. In the present study, the winter abundance in the field neither of flagellates (1.6 to $3.5 \mathrm{mg} \mathrm{C} \mathrm{m}^{-3}$ ) or ciliates (0.6 to $1.3 \mathrm{mg} \mathrm{C} \mathrm{m}^{-3}$ ) was high enough to sustain basic metabolism, let alone reproduction. Thus, during winter, $O$. similis may have been supported by an alternative food source such as the nauplii of small copepod species and/or the faecal pellets of euphausids which were found in the net samples.

The average GGE of $47 \%$ estimated in the present study, is higher than the often-used value of $30 \%$ (Ikeda \& Motoda 1978) and the mean of $26 \%$ reported in Straile's (1997) review for copepods. However, in copepods, GGE can range from $<10$ to $80 \%$ (Straile 1997, Dam \& Lopes 2003), and among other factors it can be affected by the chemical composition of the diet. For instance, an increase in nitrogen content of the diet resulted in an increase in the GGE of the copepod Paracalanus parvus (Checkley 1980). Indeed, the GGE estimated in the present study, increased significantly with an increase in the percentage of ciliate carbon in the diet of Oithona similis (Fig. 7).

Given the preponderantly carnivorous diet of Oithona spp., in the present study, a GGE higher than that of more herbivorous copepods may not be unlikely, as diatoms and phytoplankton in general are considered to be less digestible, less nutritious and to contain less nitrogen than ciliates (Stoecker \& Capuzzo 1990, Sanders \& Wickham 1993, Klein-Breteler et al. 1999; but see Dam \& Lopes 2003). Coincidentally, at Stn C8su, where the lowest GGE of $17 \%$ was estimated, $\sim 90 \%$ of the diet was composed of flagellates. A high GGE could represent an important evolutionary adaptation for a copepod like $O$. similis, living in a relatively 'food-diluted' environment. It is important to remember, however, that GGE is a derived parameter (i.e. the ratio between EPR and ingestion rate) and not a direct measurement. Thus, in the present study, the GGE might have been overestimated (i.e. GGE $>100 \%$ ), by using the EPR of a population (i.e. net samples) rather than of individual females incubated in feeding experiments. Future research will be required to elucidate whether Oithona spp. egg production efficiency is higher than that of other copepod groups.

\section{CONCLUSION}

By investigating the feeding ecology of Oithona similis over a wide temporal and spatial scale the present study has shown that microzooplankton, particularly Strombidium spp. ciliates were the main food sources for $O$. similis in the Irminger Basin and in the Iceland Basin. Other food items were only ingested when ciliate abundance became scarce.

There was a positive relationship between GGE and the percentage of ciliates in the diet, suggesting that microzooplankton had a higher nutritional vlaue for Oithona similis than other components of the microplankton.

Estimates of GGE > 100, particularly in winter, suggest that ingestion was underestimated and that reproduction might have been supported by alternative prey which could not be taken into account by the feeding experiments.

Acknowledgements. This study was funded by the Natural Environment Research Council thematic programme Marine Productivity (grant NER/T/S/2001/00140). We wish to thank E. Fileman, D. Montagnes, Thomas Kiørboe and 3 anonymous referees for improving the paper with their comments. We also thank D. Harbour for carrying out the microplankton analysis and K. Drif for helping with the picking of Oithona similis. 


\section{LITERATURE CITED}

Atkinson A (1996) Subantarctic copepods in an oceanic, low chlorophyll environment: ciliate predation, food selectivity and impact on prey populations. Mar Ecol Prog Ser 130: 85-96

Atkinson A (1998) Lyfe cycle strategies of epipelagic copepods in the Southern Ocean. J Mar Syst 15:289-311

Atkinson A, Shreeve RS (1995) Response of copepod community to a spring bloom in the Bellingshausen Sea. DeepSea Res II 42:1291-1311

Båmstedt U, Gifford D, Atkinson A, Irigoien X, Roman M (2002) Zooplankton feeding. In: Harris RP, Wiebe P, Lenz J, Skjoldal HR, Huntley M (eds) ICES zooplankton methodology manual. Academic Press, London, p 297-399

Burkill PH, Edwards ES, John AWG, Sleigh MA (1993) Microzooplankton and their herbivorous activity in the northeastern Atlantic Ocean. Deep-Sea Res II 40:479-493

Castellani C, Robinson C, Smith T and Lampitt R (2005) Do temperature changes affect the respiration rate of Oithona similis? Mar Ecol Prog Ser 285:129-135

Checkley DM (1980) The egg production of a marine planktonic copepod in relation to its food supply: laboratory studies. Limnol Oceanogr 25:430-446

Dam HG, Lopes RM (2003) Omnivory in the calanoid copepod Temora longicornis: feeding egg production and egg hatching rates. J Exp Mar Biol Ecol 292:119-137

Drits AV, Semenova TN (1984) Experimental investigations of the feeding of Oithona similis Claus. Okeanologiya 24: 755-759

Edmondson WT (1971) Reproductive rates determined directly from egg ratio. In: Edmondson WT, Winberg GG (eds) A manual on methods for assessment of secondary production in fresh waters. Blackwell Scientific, Oxford, p 165-169

Frost BW (1972) Effects of size and concentration of food particles on the feeding behaviour of the marine planktonic copepod Calanus pacificus. Limnol Oceanogr 17:805-815

Gonzalez HE, Smetacek V (1994) The possible role of the cyclopoid copepod Oithona in retarding vertical flux of zooplankton faecal material. Mar Ecol Prog Ser 113: 233-246

Hopkins TL, Lancraft TM, Torres JJ, Donnelly J (1993) Community structure and trophic ecology of zooplankton in the Scotia Sea marginal ice zone in winter (1988). Deep-Sea Res 40:81-105

Huntley M, Lopez MDG (1992) Temperature dependent growth production of marine copepods: a global synthesis. Am Nat 140:201-242

Ikeda T, Motoda S (1978) Estimated zooplankton production and their ammonia excretion in the Kuroshio and adjacent seas. Fish Bull (Wash DC) 76:357-367

Kiørboe T, Sabatini M (1994) Reproductive and life-cycle strategies in egg-carrying cyclopoid and free-spawning calanoid copepods. J Plankton Res 16:1353-1366

Kiørboe T, Mohlenberg F, Hamburger K (1985) Bioenergetics of the planktonic copepod Acartia tonsa: relation between feeding, egg production and respiration, and composition of specific dynamic action. Mar Ecol Prog Ser 26:85-97

Klein-Breteler, VCM, Schogt N, Baars M, Schouten S and Kraay GW (1999) Trophic upgrading of food quality by protozoans enhancing copepod growth: role of essential lipids. Mar Biol 135:191-198

Lampitt RS (1978) Carnivorous feeding by a small marine copepod. Limnol Oceanogr 23:1228-1230

Lampitt RS, Gamble JC (1982) Diet and respiration of the

Editorial responsibility: Thomas Kiørboe (Contributing Editor), Charlottenlund, Denmark small planktonic marine copepod Oithona nana. Mar Biol 66:185-190

Lessard EJ, Swift E (1986) Dinoflagellates from the North Atlantic classified as phototrophic or heterotrophic by epifluorescence microscopy. J Plankton Res 8: 1209-1215

Lonsdale DJ, Caron DA, Dennet MR, Schaffner R (2000) Predation by Oithona spp. on protozooplankton in the Ross Sea, Antarctica. Deep-Sea Res II 47:3273-3283

Manly BFJ (1974) A model for certain types of selection experiments. Biometrics 30:281-294

McKinnon AD, Klumpp DW (1998) Mangrove zooplankton of North Queensland, Australia: I. Plankton community structure and environment. Hydrobiologia 362:127- 143

Nakamura Y, Turner JT (1997) Predation and respiration by the small cyclopoid copepod Oithona similis: How important is feeding on ciliates and heterotrophic flagellates? J Plankton Res 19:1275-1288

Nielsen TG, Kiørboe T (1994) Regulation of zooplankton biomass and production in a temperate coastal ecosystem: ciliates. Limnol Oceanogr 39:508-519

Nielsen TG, Sabatini M (1996) Role of cyclopoid copepods Oithona spp. in North Sea plankton communities. Mar Ecol Prog Ser 139:79-93

Nielsen TG, Møller EF, Satapoomin S, Ringuette M, Hopcroft RR (2002) Egg hatching rate of the cyclopoid copepod Oithona similis in arctic and temperate waters. Mar Ecol Prog Ser 236:301-306

Paffenhöfer GA (1993) On the ecology of marine cyclopoid copepods (Crustacea, Copepoda). J Plankton Res 15:37-55

Paffenhöfer GA, Mazzocchi MG (2002) On some aspect of the behaviour of Oithona plumifera (Copepoda: Cyclopoida). J Plankton Res 24:129-135

Putt M, Stoecker DK (1989) An experimentally determined carbon:volume ratio for marine 'oligotrichous' ciliates from estuarine and coastal waters. Limnol Oceanogr 34: 1097-1103

Sabatini M, Kiørboe T (1994) Egg production, growth and development of the cyclopoid copepod Oithona similis. J Plankton Res 16:1329-1351

Sanders RM, Wickham SA (1993) Planktonic Protozoa and Metazoa: predation, food quality and population control. Mar Microb Food Webs 7:197-223

Stoecker DK, Capuzzo JM (1990) Predation on protozoa: its importance to zooplankton. J Plankton Res 12:891-908

Straile D (1997) Gross-growth efficiencies of protozoan and metazoan zooplankton and their dependence on food concentration, predator-prey weight ratio and taxonomic group. Limnol Oceanog 42:1375-1385

Strathmann RR (1967) Estimating the organic carbon content of phytoplankton from cell volume or plasma volume. Limnol Oceanogr 12: 411-418

Svensen C, Kiørboe T (2000) Remote prey detection in Oithona similis: hydromechanical versus chemical cues. J Plankton Res 22:1155-1166

Turner JT, Graneli E (1992) Zooplankton feeding ecology: grazing during enclosure studies of the phytoplankton blooms from the west coast of Sweden. J Exp Mar Biol Ecol 157:19-31

Uchima U, Hirano R (1986) Food of Oithona davisae (Copepoda: Cyclopoida) and the effect of food concentration at first feeding on the larval growth. Bull Plankton Soc Jpn 33:21-28

Utermöhl H (1958) Zur Vervollkommnung der quantitativen Phytoplankton Methodik. Mitt Int Ver Theor Angew Limnol 9:1-38

Submitted: January 21, 2004; Accepted: September 28, 2004 Proofs received from author(s): February 17, 2005 